Zeszyty Naukowe Szkoły Głównej Gospodarstwa Wiejskiego w Warszawie

Problemy Rolnictwa Światowego tom 18 (XXXIII), zeszyt 2, 2018: 207-217

DOI: 10.22630/PRS.2018.18.2.48

Katarzyna Łukiewska ${ }^{1}$, Malgorzata Juchniewicz ${ }^{2}$

Uniwersytet Warmińsko-Mazurski w Olsztynie

\title{
Bariery rozwoju gospodarstw rolnych użytkujących grunty z Zasobu Własności Rolnej Skarbu Państwa
}

\section{Barriers to the Development of Farms Using Land from the Agricultural Property Resources of the State Treasury}

\begin{abstract}
Synopsis. Zachodzące przekształcenia społeczno-gospodarcze, w tym procesy liberalizacji i globalizacji, wzrost konkurencji oraz zmieniające się oczekiwania nabywców powodują, że warunki w jakich funkcjonuje rolnictwo są coraz bardziej złożone. Celem badań było określenie barier rozwoju gospodarstw rolnych w opinii rolników, którzy w swojej działalności użytkowali grunty pochodzące z Zasobu Własności Rolnej Skarbu Państwa (ZWRSP). Badaniem objęto 167 gospodarstw zlokalizowanych na obszarze województwa warmińsko-mazurskiego. Uzyskane wyniki przedstawiono dla całej badanej grupy oraz w zależności od formy zagospodarowania gruntów pochodzących z ZWRSP. Z przeprowadzonych badań wynika, że rozwój gospodarstw rolnych zdaniem badanych hamowany jest głównie przez czynniki kosztowo-cenowe, takie jak: niestabilne ceny skupu, wysokie koszty produkcji rolniczej, wysokie ceny na środki produkcji oraz brak kapitału na rozwój.
\end{abstract}

Słowa kluczowe: gospodarstwo rolne, rozwój, bariery rozwoju, województwo warmińsko-mazurskie

\begin{abstract}
The ongoing socio-economic transformations in Poland, including the processes of liberalization and globalization, increased competition and changing expectations of buyers cause the conditions in which agriculture operates to be more and more complex. The purpose of the research was to identify barriers to the development of farms, in the opinion of farmers who in their operation used land from the Agricultural Property Resources of the State Treasury (ZWRSP). The study covered 167 farms located in the area of Warmian-Masurian Voivodeship. The obtained results were presented for the entire studied group and according to the form of land management from the ZWRSP. The research shows that the development of farms, according to the respondents, is mainly inhibited by cost and price factors, such as: unstable purchase prices, high costs of agricultural production, high prices for means of production and lack of capital for development.
\end{abstract}

Key words: farms, development, barriers to development, Warmian-Masurian Voivodeship

JEL Classification: O13, Q13

\section{Wprowadzenie}

Sektor rolny jest początkowym ogniwem w łańcuchu żywnościowym i podstawowym elementem podażowej strony rynku rolnego (Gołębiewski, 2014). Jego funkcjonowanie związane jest z różnymi płaszczyznami aktywności gospodarczej: społeczną, ekonomiczna,

\footnotetext{
${ }^{1}$ mgr, Katedra Ekonomiki Przedsiębiorstw UWM, ul. M. Oczapowskiego 4, 10-719 Olsztyn, e-mail: katarzyna.lukiewska@uwm.edu.pl

${ }^{2}$ dr hab., prof. UWM, Katedra Ekonomiki Przedsiębiorstw UWM, ul. M. Oczapowskiego 4, 10-719 Olsztyn, e-mail: malgorzata.juchniewicz@uwm.edu.pl
} 
a także środowiskową. Główną funkcją rolnictwa jest produkcja żywności najważniejszego produktu ludzkości. Pełni on zatem znaczącą rolę $\mathrm{w}$ zaspokajaniu podstawowych potrzeb społeczeństwa. Kosior (2017) wskazuje, że w warunkach rozwiniętej świadomości konsumenckiej oraz zmieniających się trendów żywnościowych rosną oczekiwania wobec dostarczanych przez rolnictwo i cały sektor żywnościowy produktów w zakresie jakości i bezpieczeństwa żywności oraz pozytywnego wpływu na zdrowie. Rolnictwo jest także ważnym sektorem polskiej gospodarki. Znajduje to potwierdzenie w tworzeniu PKB, strukturze zatrudnienia ludności (zwłaszcza na obszarach wiejskich), a także strukturze użytkowania gruntów. Wartość dodana brutto wytworzona w rolnictwie w Polsce wynosiła w 2016 r. 38 469,9 mln zł, a zatrudnienie w tym sektorze prawie 2 328,6 tys. osób, czyli 15,6\% wszystkich zatrudnionych w kraju (Rocznik statystyczny rolnictwa 2017, Rocznik statystyczny pracy 2017). Udział rolnictwa w Polsce w tworzeniu PKB w porównaniu do średniej UE jest relatywnie wysoki i wynosi ponad 2\% (podobnie jak w Bułgarii, Estonii, Grecji, Hiszpanii, na Litwie, w Rumunii i na Wegrzech). W całej UE odsetek ten kształtuje się na poziomie zaledwie 1,2\%. Warto dodać, że udział polskich rolników w liczbie zatrudnionych w tym sektorze w całej UE wynosił blisko $28 \%$. Oznacza to, że co trzeci europejski rolnik jest Polakiem (Ryś-Jurek, 2016). Polska posiada ponadto relatywnie duże, w porównaniu do innych państw członkowskich UE, zasoby ziemi użytkowanej rolniczo. Użytki rolne stanowią blisko połowę powierzchni kraju. Odsetek ten jest większy tylko w sześciu krajach członkowskich UE (Nowak, 2013). Z badań innych autorów wynika, że wkład rolnictwa w gospodarkę narodowa, w związku z powstającymi przeobrażeniami strukturalnymi oraz szybszym tempem wzrostu działów pozarolniczych, wykazuje tendencję malejącą (Jolanta Kondratowicz-Pozorska, 2015). Chomicz i Balewski (2012) wskazują jednak, że rolnictwo staje się, w coraz większym stopniu, czynnikiem prorozwojowym dla wszystkich wytwórców środków produkcji niezbędnych dla działalności rolniczej, jak i wszelkiego rodzaju usługodawców, ale także dla całej części gospodarki narodowej wykorzystującej w swojej działalności surowce pochodzenia rolniczego. Zgodnie $\mathrm{z}$ istotą rolnictwa zrównoważonego sektor ten powinien równocześnie i harmonijne, obok celów produkcyjnych, realizować także cele pozaprodukcyjne. Krzyżanowski (2014) podkreśla, że zrównoważony rozwój kraju nie jest możliwy bez rolnictwa i dbałości o zasoby naturalne oraz rozwój terytorialny. Autor ten wskazuje, że rolnictwo w Polsce ma decydujący wpływ na bezpieczeństwo żywnościowe, sytuację społeczno-ekonomiczną mieszkańców obszarów wiejskich, stan środowiska przyrodniczego oraz strukturę krajobrazu. Rolnictwo wyznacza główne funkcje i kierunki użytkowania ziemi oraz kształtuje środowisko przyrodnicze i krajobraz. Od gospodarki rolnej zależy w znacznym stopniu czystość wód, powietrza i gleby oraz różnorodność gatunków roślin i zwierząt. Kołoszko-Chomentowska i Sieczko (2014) wyrażają pogląd, że kwestia gospodarstw rolnych jest sprawą całego społeczeństwa, a nie tylko rolników i ich rodzin. Autorzy podkreślają że problematyka gospodarstw rolnych jest ciagle aktualna i powinna być podejmowania oraz upowszechniana nie tylko $\mathrm{w}$ środowisku ściśle związanym z tym działem gospodarki.

Zadania $\mathrm{i}$ wyzwania stojące przed rolnictwem związane są nie tylko z rosnącymi oczekiwaniami dotyczącymi m.in. bezpieczeństwa żywności czy ochrony zasobów naturalnych, ale także ze zmianami gospodarczymi występującymi w ostatnich latach w polskiej i światowej gospodarce. Przejście od gospodarki centralnie sterowanej do gospodarki rynkowej oraz przystapienie Polski do UE, sprawiły, że warunki w jakich funkcjonują gospodarstwa rolne stały się trudniejsze i bardziej złożone (Wołoszyn, 2004). 
Zachodzące procesy globalizacji i liberalizacji, intensywny rozwój współczesnych gospodarek, szybki postęp technologicznych oraz zmieniające się oczekiwania nabywców spowodowały ponadto wzrost intensywności i zasięgu konkurencji. $Z$ badań przeprowadzonych przez innych autorów wynika, że rolnictwo w Polsce wypada relatywnie niekorzystnie na tle większości krajów UE pod względem rozdrobnienia agrarnego oraz efektów produkcyjno-dochodowych. Niewielka przeciętna powierzchnia gospodarstwa rolnego, a także duża liczba gospodarstw najmniejszych utrudnia polskiemu rolnictwu możliwości konkurowania z rolnictwem UE (Bański, 2010). Małe gospodarstwa rolne mają ograniczone możliwości modernizacji produkcji, przez co osiąają niższe, niż przeciętnie w UE, wyniki. Według Nowaka (2016) produktywność pracy w rolnictwie w Polsce wynosiła latach 2009-2013 jedynie 27,2\% średniego unijnego poziomu. Niższą efektywność wykorzystania pracy odnotowano jedynie w Bułgarii, Rumunii i w Słowacji. Luka w odniesieniu do średniej unijnej wystąpiła także w zakresie produktywności ziemi oraz produktywności kapitału (Nowak 2016). Z badań przeprowadzonych przez Ryś-Jurek (2016) wynika, że Polska znajdowała się w 2013 r. dopiero na 23. miejscu w rankingach wartość produkcji ogółem oraz średniego dochodu na 1 gospodarstwo rolne. Wartość produkcji ogółem przypadająca na 1 gospodarstwo rolne w Polsce w 2013 r. wynosiła średnio 31390 euro i była aż o 38956 euro niższa niż w całej UE. Średni dochód z rodzinnego gospodarstwa rolnego w Polsce wynosił natomiast 9835 euro, podczas gdy w całej UE - 17903 euro.

W literaturze przedmiotu wskazywanych jest wiele potencjalnych barier mogących ograniczać rozwój gospodarstw rolnych. Według Tomczaka (2005) są to: bariery małej skali produkcji, bariery niedostatecznych zdolności do inwestycji i akumulacji, bariery nadmiaru lub niedoboru siły roboczej, bariery dochodowe, bariery wyposażenia technicznego i zdolności przyjęcia i stosowania nowych technologii, bariery społecznosocjologiczne związane $\mathrm{z}$ charakterem zatrudnienia, brakiem wolnego czasu, ograniczonymi możliwościami kształcenia i prymitywnymi warunkami życia. Autor ten wskazuje również na niski stopień funkcjonowania w grupach producenckich. Niektórzy autorzy dzielą bariery rozwoju rolnictwa na dwie grupy: egzogeniczne i endogeniczne. Pierwsza z tych grup obejmuje czynniki, na które rolnicy nie mają wpływu. Zalicza się do nich m.in. czynniki demograficzne (np. liczba i struktura wiekowa ludności), czynniki ekonomiczne (np. stopa wzrostu gospodarczego, struktura i poziom cen), czynniki społeczno-kulturowe (np. wzorce wydatków ludności, preferencje), czynniki przyrodnicze (np. zasoby surowców, ilość i jakość użytków rolnych), czynniki technologiczne (np. wdrażanie nowych technologii) oraz czynniki polityczno-prawne (np. polityka rolna rządu) (Kurdyś-Kujawska, 2013). Do drugiej grupy należą natomiast głównie czynniki dotyczące zasobów gospodarstwa (naturalnych, majątkowych, pracy). Do tej grupy zaliczyć można również czynniki związane $\mathrm{z}$ wykształceniem, wiekiem, przedsiębiorczością, a także podejściem i umiejętnościami rolników w zakresie procesu zarządzania gospodarstwem (Kurdyś-Kujawska, 2013; Sulewski, 2008). W rozwoju rolnictwa szczególne znaczenie ma ziemia. Zarówno zakup, jak i dzierżawa gruntów umożliwiają wykorzystania większej powierzchni produkcyjnej w gospodarstwach rolniczych i stwarzają szansę na zwiększenie skali działania i korzyści z tym związanych. Istotnym potencjalnym źródłem ziemi dla rolników jest Zasób Własności Rolnej Skarbu Państwa (ZWRSP). W 2016 r. wprowadzona została Ustawa o wstrzymaniu sprzedaży nieruchomości Zasobu Własności Rolnej Skarbu Państwa oraz o zmianie niektórych ustaw, której podstawowym celem jest ochrona polskiej ziemi przed niekontrolowanym wykupem. Na podstawie wprowadzonych regulacji m.in. 
wstrzymano sprzedaż nieruchomości wchodzących w skład ZWRSP w okresie 5 lat od dnia wejścia w życie ustawy, a preferowaną formą zagospodarowania nieruchomości wchodzących w skład ZWRSP stała się dzierżawa. Ze względu na wprowadzane zmiany w polityce państwa dotyczącej gospodarowaniem mieniem ZWRSP, ważne i aktualne jest badanie podmiotów gospodarczych mających doświadczenia praktyczne dotyczące determinant i efektywności wykorzystania różnych form zagospodarowania gruntów z ZWRSP. W kontekście powyższych rozważań celem przeprowadzonych badań było określenie barier rozwoju gospodarstw rolnych w opinii rolników, którzy w swojej działalności użytkowali grunty zakupione i/lub dzierżawione z ZWRSP. Identyfikacja czynników ograniczających rozwój badanych gospodarstw rolnych w Polsce może ułatwić prowadzenie szeroko pojętej, celowej i skutecznej działalności wspierającej ich funkcjonowanie i konkurencyjność.

\section{Dane i metody}

Wyniki badań własnych zostały opracowane na podstawie danych zgromadzonych za pomoca przeprowadzonego w 2017 r. sondażu diagnostycznego. Podmiotem badań była celowo dobrana grupa gospodarstw rolniczych zlokalizowanych na obszarze województwa warmińsko-mazurskiego, wykorzystująca $\mathrm{w}$ swoich działaniach grunty $\mathrm{z}$ Zasobów Własności Rolnej Skarbu Państwa (ZWRSP) ${ }^{3}$. W badaniu wzięło udział 167 gospodarstw. Rozmieszone one były we wszystkich powiatach województwa warmińsko-mazurskiego. Średnia powierzchnia analizowanym podmiotów wynosiła 85 ha. Badani rolnicy charakteryzowali się najczęściej wykształceniem średnim (49,7\%). Relatywnie dużą grupę reprezentowały osoby z wykształceniem zasadniczym zawodowym $(28,1 \%)$ oraz wyższym $(18,6 \%)$. Najmniej respondentów posiadało wykształcenie podstawowe $(3,6 \%)$. Największy udział w strukturze wieku właścicieli badanych gospodarstw miała grupa osób w wieku 41-60 lat (51,6\%), następnie 21- 40 lat (38,3\%). Najmniejszą grupę w badanej zbiorowości stanowili respondenci mający więcej niż 61 lat. W badanych gospodarstwach prowadzono zarówno produkcję roślinna, jak i zwierzęcą. Jako podstawowe uprawy wymieniano zboża (91,6\%), użytki zielone $(77,8 \%)$ oraz rośliny motylkowe $(53,3 \%)$. Rzadziej ankietowani zajmowali się produkcją roślin oleistych $(26,9 \%)$ i okopowych $(24,6 \%)$ oraz uprawami ogrodniczymi (3,6\%). Respondenci deklarowali ponadto, że najczęściej hodowanymi zwierzętami było bydło mleczne (41\%), z kolei najrzadziej hodowano drób (7\%). Zastosowany kwestionariusz badawczy, obok metryczki, zawierał zestaw pytań dotyczących opinii właścicieli gospodarstw rolniczych na temat najważniejszych uwarunkowań rozwoju i konkurencyjności gospodarstw przy różnych formach zagospodarowania gruntów pochodzących z ZWRSP (m.in. źródeł przewagi konkurencyjnej, działań wewnętrznych realizowanych w celu poprawy konkurencyjności, stosowanych instrumentów konkurowania, identyfikacji barier rozwoju oraz określenia najważniejszych zalet $\mathrm{i}$ wad dzierżawy oraz własności gruntów rolnych). W zakresie czynników ograniczających rozwój gospodarstw rolnych respondenci zostali poproszeni o

\footnotetext{
${ }^{3}$ Realizacja badań była możliwa dzięki współpracy z Oddziałem Terenowym ANR w Olsztynie oraz WarmińskoMazurskim Ośrodkiem Doradztwa Rolniczego w Olsztynie, a przedstawione w opracowaniu wyniki badań stanowią część materiału uzyskanego w ramach projektu badawczego sfinansowanego przez Uniwersytet Warmińsko-Mazurski w Olsztynie i Agencję Nieruchomości Rolnych Oddział Terenowy w Olsztynie.
} 
ocenę wybranych 18 barier rozwoju w skali punktowej od 0 do 3 ( 0 - brak znaczenia, 1 niskie znaczenie, 2 - średnie znaczenie, 3 - wysokie znaczenie). Do opracowania uzyskanych wyników badań wykorzystano wybrane statystyki opisowe, w tym miary położenia i rozproszenia rozkładu cech. Były to średnia arytmetyczna, mediana (wartość środkowa - wartość cechy w szeregu uporządkowanym, powyżej i poniżej której znajduje się jednakowa liczba obserwacji), dominanta (wielkość występująca najczęściej w zbiorze danych) oraz współczynnik zmienności (stanowiący iloraz odchylenia standardowego i średniej arytmetycznej, określający poziom zróżnicowania cechy). Uzyskane wyniki przedstawiono w odniesieniu do całej badanej grupy, a także z podziałem na trzy podgrupy podmiotów wyodrębnione ze względu na formę zagospodarowania gruntów pochodzących z ZWRSP (gospodarstwa, w których jednocześnie zakupiono i dzierżawiono grunty pochodzące z ZWRSP, gospodarstwa, w których tylko zakupiono grunty pochodzące ZWRSP oraz gospodarstwa, w których tylko dzierżawiono grunty pochodzące z ZWRSP).

\section{Wyniki badań}

Z przeprowadzonych badań wynika, że zdaniem rolników rozwój gospodarstw rolnych hamowany jest głównie przez czynniki kosztowo-cenowe. Do najważniejszych barier utrudniających prowadzenie i wzrost działalności rolniczej respondenci zaliczyli niestabilne ceny skupu oraz wysokie koszty produkcji rolniczej (tab. 1). Świadczy o tym najwyższa spośród wszystkich ocenianych elementów średnia arytmetyczna, która wynosiła 2,7 pkt oraz wysokie wielkości analizowanych miar pozycyjnych (tab. 2). Mediana oraz dominanta dla obu czynników przyjęła najwyższą możliwą wielkość, tj. 3 pkt. Warto podkreślić, że aż $77,0 \%$ badanych uznało niestabilne ceny skupu, a 71,0\% ankietowanych wysokie koszty produkcji rolniczej jako bardzo ważne czynniki ( $3 \mathrm{pkt})$. Wysokie koszty produkcji rolniczej były ponadto jedynym czynnikiem ocenionym na co najmniej 1 pkt. Nikt z badanych zatem nie uznał, że czynnik ten w żadnym stopniu nie utrudnia prowadzenia działalności. Niski współczynnik zmienności na tle pozostałych analizowanych elementów wskazuje na dużą zgodność respondentów w ocenie obu wskazanych czynników. Relatywnie duże znaczenie, zdaniem respondentów, miały także wysokie ceny na środki produkcji oraz brak kapitału na rozwój. Odpowiednio $64,0 \%$ i $58,0 \%$ badanych uznało, że są to bariery o wysokim znaczeniu, a kolejne $26,0 \%$ i 34,0\% o średnim. Przeciętne oceny tych czynników wyniosły 2,5 pkt. Mediana i dominanta kształtowały się na poziomie 3 pkt. Współczynnik zmienności kształtował się na relatywnie niskim poziomie $(27,0 \%-28,0 \%)$. Wskazuje to na małe zróżnicowanie ocen.

Respondenci zwrócili również uwagę na skomplikowane procedury uzyskania dotacji z Unii Europejskiej. Niemal 61,0\% badanych uznało, że są one istotne w dużym stopniu, a 26,0\% w średnim stopniu. Tylko 4,2\% ankietowanych uznało, że złożoność tych procedur nie ma znaczenia w rozwoju prowadzonych gospodarstw rolniczych. Średnia arytmetyczna ocen analizowanej bariery wyniosła 2,4 , a mediana 3 pkt. Do grupy ważnych bariery rozwoju gospodarstw rolnych, zdaniem badanych, należy zaliczyć także przestarzały park maszynowy oraz wysoki poziom opodatkowania (podatek gruntowy, ubezpieczenia majątku, składki na ubezpieczenie społeczne). Istotne znaczenie (3 pkt) kapitałowych barier rozwoju dostrzegło $44,0 \%$ badanych. Duże znaczenie (3 pkt) opodatkowania wskazywało natomiast $35,0 \%$ ankietowanych. 


\section{K. Eukiewska, M. Juchniewicz}

Relatywnie rzadziej ankietowani postrzegali czynniki związane z dzierżawą jako bariery rozwoju. Średnia arytmetyczna ocen poziomu czynszu dzierżawnego, regulacji formalno-prawnych dotyczących dzierżawy gruntów oraz jakości dzierżawionych gruntów kształtowała się na poziomie $2,0 \mathrm{pkt}-2,1$ pkt. Niektórzy respondenci uważają zatem, że poprawa w zakresie tych czynników mogłaby polepszyć funkcjonowanie przedsiębiorstw. Wydaje się jednak, że dzierżawa nie ogranicza, a sprzyja rozwojowi gospodarstw rolnych. Pozwala bowiem powiększać zasób użytkowanej ziemi nie angażując dużego kapitału koniecznego do nabycia gruntów. Ma to szczególnie duże znaczenie w przypadku małych gospodarstw oraz tych w gorszej sytuacji finansowej.

Tabela 1. Wybrane bariery rozwoju gospodarstw rolnych użytkujących grunty z ZWRSP

Table 1. Selected barriers to the development of farms using land from the ZWRSP

\begin{tabular}{|c|c|c|c|c|}
\hline \multirow{3}{*}{ Bariery rozwoju } & \multicolumn{4}{|c|}{ Liczba punktów } \\
\hline & 0 & & 2 & 3 \\
\hline & \multicolumn{4}{|c|}{ \% wskazań } \\
\hline niestabilne ceny skupu & 0,60 & 6,59 & 16,17 & 76,65 \\
\hline wysokie koszty produkcji rolniczej & 0,00 & 3,59 & 25,75 & 70,66 \\
\hline wysokie ceny na środki produkcji & 0,60 & 9,64 & 25,90 & 63,86 \\
\hline brak kapitału na rozwój & 1,20 & 7,78 & 33,53 & 57,49 \\
\hline $\begin{array}{l}\text { skomplikowane procedury uzyskania dotacji z Unii } \\
\text { Europejskiej }\end{array}$ & 4,19 & 9,58 & 25,75 & 60,48 \\
\hline przestarzały park maszynowy & 5,39 & 14,37 & 36,53 & 43,71 \\
\hline $\begin{array}{l}\text { wysoki poziom opodatkowania (podatek gruntowy, } \\
\text { ubezpieczenia majątku, składki na ubezpieczenia społeczne) }\end{array}$ & 1,20 & 19,16 & 44,31 & 35,33 \\
\hline wysoki poziom czynszu dzierżawnego & 4,82 & 16,27 & 40,96 & 37,95 \\
\hline $\begin{array}{l}\text { skomplikowane i niestabilne regulacje formalno-prawne } \\
\text { dotyczące dzierżawy gruntów }\end{array}$ & 6,59 & 15,57 & 43,11 & 34,73 \\
\hline niska jakość dzierżawionych gruntów & 5,39 & 22,16 & 43,11 & 29,34 \\
\hline dostęp do właściwych pracowników & 7,78 & 25,75 & 30,54 & 35,93 \\
\hline złe warunki klimatyczne & 8,98 & 19,16 & 41,32 & 30,54 \\
\hline ograniczony popyt na produkty wytwarzane w gospodarstwie & 9,58 & 20,36 & 38,92 & 31,14 \\
\hline $\begin{array}{l}\text { ograniczony dostęp do kredytów (wysokie wymagania } \\
\text { formalno-prawne i koszty obsługi kredytu) }\end{array}$ & 8,98 & 22,75 & 43,11 & 25,15 \\
\hline biurokracja ANR & 7,19 & 26,35 & 41,92 & 24,55 \\
\hline $\begin{array}{l}\text { niskie i nieodpowiednie kwalifikacje siły roboczej na lokalnym } \\
\text { rynku }\end{array}$ & 10,78 & 35,93 & 20,96 & 32,34 \\
\hline niekorzystne położenie geograficzne gospodarstwa & 13,77 & 27,54 & 37,72 & 20,96 \\
\hline brak informacji o rynku & 16,87 & 31,93 & 33,73 & 17,47 \\
\hline
\end{tabular}

Źródło: opracowanie własne na podstawie badań.

Najmniejsze znaczenie według badanych miały czynniki, takie jak: dostęp do właściwych pracowników, złe warunki klimatyczne, ograniczony popyt na produkty wytwarzane w gospodarstwie, ograniczony dostęp do kredytów (wysokie wymagania formalno-prawne i koszty obsługi kredytu), biurokracja ANR, niskie i nieodpowiednie kwalifikacje siły roboczej na lokalnym rynku, niekorzystne położenie geograficzne gospodarstwa oraz brak informacji o rynku. Ankietowani rolnicy relatywnie rzadziej 
wskazywali na wysokie znaczenie tych czynników w rozwoju gospodarstw. Średnia arytmetyczna ocen wynosiła od 1,5 pkt do 1,9 pkt, a dominanta 1 pkt lub 2 pkt. Wśród respondentów były także osoby, które uważały, że analizowane czynniki w żadnym stopniu nie utrudniają prowadzenia gospodarstw rolniczych. Najliczniejsza grupa miała taką opinię na temat braku informacji o rynku (17\%), niekorzystnego położenia geograficznego gospodarstw (14\%) oraz niskich i nieodpowiednich kwalifikacji siły roboczej na lokalnym rynku (11\%). Współczynnik zmienności na relatywnie wysokim poziomie $(48 \%-64 \%)$ wskazuje, że rozkład otrzymanych odpowiedzi w przypadku tego rodzaju uwarunkowań był zróżnicowany.

Tabela 2. Wybrane bariery rozwoju gospodarstw rolnych użytkujących grunty z ZWRSP - statystyki opisowe

Table 2. Selected barriers to the development of farms using land from the ZWRSP - descriptive statistics

\begin{tabular}{|c|c|c|c|c|}
\hline Bariery rozwoju & Śr & $\mathrm{Me}$ & $\mathrm{D}$ & $\mathrm{Zm} .(\%)$ \\
\hline niestabilne ceny skupu & 2,69 & 3 & 3 & 23,06 \\
\hline wysokie koszty produkcji rolniczej & 2,67 & 3 & 3 & 20,32 \\
\hline wysokie ceny na środki produkcji & 2,53 & 3 & 3 & 27,41 \\
\hline brak kapitału na rozwój & 2,47 & 3 & 3 & 28,01 \\
\hline skomplikowane procedury uzyskania dotacji z Unii Europejskiej & 2,43 & 3 & 3 & 34,29 \\
\hline przestarzały park maszynowy & 2,19 & 2 & 3 & 40,06 \\
\hline $\begin{array}{l}\text { wysoki poziom opodatkowania (podatek gruntowy, ubezpieczenia } \\
\text { majątku, składki na ubezpieczenia społeczne) }\end{array}$ & 2,14 & 2 & 2 & 35,54 \\
\hline wysoki poziom czynszu dzierżawnego & 2,12 & 2 & 2 & 40,15 \\
\hline $\begin{array}{l}\text { skomplikowane i niestabilne regulacje formalno-prawne dotyczące } \\
\text { dzierżawy gruntów }\end{array}$ & 2,06 & 2 & 2 & 42,53 \\
\hline niska jakość dzierżawionych gruntów & 1,96 & 2 & 2 & 43,61 \\
\hline dostęp do właściwych pracowników & 1,95 & 2 & 3 & 49,58 \\
\hline złe warunki klimatyczne & 1,93 & 2 & 2 & 47,87 \\
\hline ograniczony popyt na produkty wytwarzane w gospodarstwie & 1,92 & 2 & 2 & 49,41 \\
\hline $\begin{array}{l}\text { ograniczony dostęp do kredytów (wysokie wymagania formalno- } \\
\text { prawne i koszty obsługi kredytu) }\end{array}$ & 1,84 & 2 & 2 & 49,07 \\
\hline biurokracja ANR & 1,84 & 2 & 2 & 47,89 \\
\hline $\begin{array}{l}\text { niskie i nieodpowiednie kwalifikacje siły roboczej na lokalnym } \\
\text { rynku }\end{array}$ & 1,75 & 2 & 1 & 58,79 \\
\hline niekorzystne położenie geograficzne gospodarstwa & 1,66 & 2 & 2 & 57,98 \\
\hline brak informacji o rynku & 1,52 & 2 & 2 & 63,94 \\
\hline
\end{tabular}

Śr - średnia arytmetyczna, Me - mediana, D - dominanta, Zm. - współczynnik zmienności.

Źródło: opracowanie własne na podstawie badań.

Rozpatrując opinie rolników z uwzględnieniem form zagospodarowania gruntów pochodzących z ZWRSP, można zauważyć niewielkie zróżnicowanie ocen analizowanych barier rozwoju gospodarstw rolnych (tab. 3). Niezależnie od form zagospodarowania gruntów do głównych barier rozwoju gospodarstw rolnych zaliczano czynniki kosztowocenowe. W opinii rolników, który kupili grunty z ZWRSP najważniejszym czynnikiem hamującym rozwój były wysokie koszty produkcji rolniczej, a rolników, którzy dzierżawili 


\section{K. Łukiewska, M. Juchniewicz}

oraz tych, którzy jednocześnie dzierżawili i kupili grunty pochodzące z ZWRSP niestabilne ceny skupu. Rolnicy, którzy zdecydowali się na zakup gruntów częściej niż pozostali zwracali uwage na duże znaczenie przestarzałego parku maszynowego, ograniczonego popytu na produkty wytwarzane w gospodarstwie oraz biurokrację ANR. Badani, którzy w prowadzonej działalności rolniczej wykorzystywali grunty dzierżawione z ZWRSP częściej za ważny czynnik uznawali dostęp do właściwych pracowników, a rzadziej - wysoki poziom czynszu dzierżawnego. Rolnicy, którzy gospodarowali na gruntach zakupionych idzierżawionych z ZWRSP relatywnie częściej niż pozostali zwracali natomiast uwage na skomplikowane i niestabilne regulacje formalno-prawne dotyczące dzierżawy gruntów.

Tabela 3. Wybrane bariery rozwoju gospodarstw rolnych według form zagospodarowania nieruchomości z ZWRSP

Table 3. Selected barriers to the development of farms according to forms of land management form the ZWRSP

\begin{tabular}{|c|c|c|c|c|c|c|}
\hline \multirow[t]{2}{*}{ Bariery rozwoju } & \multicolumn{2}{|c|}{$\begin{array}{l}\text { Zakup } \\
\text { i dzierżawa }\end{array}$} & \multicolumn{2}{|c|}{ Zakup } & \multicolumn{2}{|c|}{ Dzierżawa } \\
\hline & Śr & $\mathrm{R}$ & Śr & $\mathrm{R}$ & Śr & $\mathrm{R}$ \\
\hline niestabilne ceny skupu & 2,5 & 1 & 2,7 & 2 & 2,8 & 1 \\
\hline wysokie koszty produkcji rolniczej & 2,5 & 2 & 2,8 & 1 & 2,7 & 2 \\
\hline wysokie ceny na środki produkcji & 2,4 & 3 & 2,6 & 4 & 2,6 & 3 \\
\hline brak kapitału na rozwój & 2,4 & 4 & 2,5 & 5 & 2,5 & 4 \\
\hline skomplikowane procedury uzyskania dotacji z Unii Europejskiej & 2,4 & 4 & 2,6 & 3 & 2,4 & 5 \\
\hline $\begin{array}{l}\text { skomplikowane i niestabilne regulacje formalno-prawne } \\
\text { dotyczące dzierżawy gruntów }\end{array}$ & 2,2 & 6 & 2,1 & 8 & 2,0 & 12 \\
\hline wysoki poziom czynszu dzierżawnego & 2,1 & 7 & 2,1 & 11 & 2,2 & 8 \\
\hline $\begin{array}{l}\text { wysoki poziom opodatkowania (podatek gruntowy, ubezpieczenia } \\
\text { majątku, składki na ubezpieczenia społeczne) }\end{array}$ & 2,0 & 8 & 2,1 & 10 & 2,2 & 7 \\
\hline przestarzały park maszynowy & 2,0 & 9 & 2,1 & 6 & 2,3 & 6 \\
\hline ograniczony popyt na produkty wytwarzane w gospodarstwie & 2,0 & 10 & 2,1 & 6 & 1,8 & 15 \\
\hline niska jakość dzierżawionych gruntów & 2,0 & 11 & 1,9 & 13 & 2,0 & 10 \\
\hline złe warunki klimatyczne & 1,9 & 12 & 2,1 & 11 & 1,9 & 13 \\
\hline biurokracja ANR & 1,9 & 13 & 2,1 & 8 & 1,7 & 16 \\
\hline dostęp do właściwych pracowników & 1,8 & 14 & 1,9 & 14 & 2,1 & 9 \\
\hline $\begin{array}{l}\text { niskie i nieodpowiednie kwalifikacje siły roboczej na lokalnym } \\
\text { rynku }\end{array}$ & 1,8 & 15 & 1,6 & 18 & 1,8 & 14 \\
\hline $\begin{array}{l}\text { ograniczony dostęp do kredytów (wysokie wymagania formalno- } \\
\text { prawne i koszty obsługi kredytu) }\end{array}$ & 1,7 & 16 & 1,8 & 16 & 2,0 & 11 \\
\hline niekorzystne położenie geograficzne gospodarstwa & 1,6 & 17 & 1,9 & 15 & 1,6 & 17 \\
\hline brak informacji o rynku & 1,4 & 18 & 1,7 & 17 & 1,5 & 18 \\
\hline
\end{tabular}

Śr - średnia arytmetyczna, $\mathrm{R}$ - ranking.

Źródło: opracowanie własne na podstawie badań.

Opinie badanych rolników na temat głównych barier rozwoju gospodarstw rolnych potwierdzają także analizy innych autorów. Z badan przeprowadzonych przez Nowak (2015) wynika, że rolnicy prowadzący działalność na terenie województwa lubuskiego 
również relatywnie często wskazywali na zbyt wysokie ceny środków produkcji rolnej i usług, a także brak własnych środków finansowych jako podstawowe czynniki hamujące rozwój prowadzonych podmiotów. Inne wskazywane czynniki to zbyt mała skala produkcji i trudności ze zbytem produktów i usług gospodarstwa. Na podstawie badań Sulewskiego (2008) stwierdzono, że zdecydowanie najważniejszy negatywny wpływ ma niska opłacalność produkcji, a także obawę przed jej dalszym spadkiem. Czynnik ten został umieszczony po stronie barier zewnętrznych. Wynika to $\mathrm{z}$ przekonania większości badanych, że zdolność do generowania zadowalających wyników finansowych zależy przede wszystkich od czynników zewnętrznych, niezależnych od rolnika. Niską opłacalność relatywnie częściej wskazywali właściciele gospodarstw małych (do 15 ha). Respondenci wskazywali także stare, zużyte środki trwałe oraz brak pieniędzy na rozwój.

Poglądy rolników w kwestii czynników negatywnie wpływających na rozwój gospodarstw są zgodne także z wskazywanymi w analizach innych autorów możliwościami przyszłego rozwoju. Z badań przeprowadzonych przez Kurdyś-Kujawską (2013) wynika bowiem, że w opinii rolników, którzy prowadzili działalność na terenie województwa zachodniopomorskiego, największe znaczenie w rozwoju gospodarstw miało ustabilizowanie cen na rynku produktów rolnych. Zdaniem rolników, modernizacja gospodarstwa, wzrost wartości aktywów i poprawa relacji między czynnikami produkcji może nastąpić także przez większy dostęp do kredytów preferencyjnych, a w szczególności kredytów inwestycyjnych. $Z$ badań tej autorki wynika także, że ponad połowa właścicieli gospodarstw rolnych, którzy skorzystali z preferencyjnych kredytów oceniła, że dostęp do tych źródeł finansowania miał istotny wpływ na podejmowane działania modernizacyjne i reorganizacyjne w gospodarstwie. Kociszewski (2014) na podstawie zrealizowanych badań podkreśla, że wzrost opłacalności produkcji może nastąpić także po podjęciu produkcji ekologicznej. Wzrost dochodów zauważyło blisko połowa badanych przez niego rolników (jedyne 16,2\% było przeciwnego zdania).

\section{Podsumowanie}

Zachodzące w ostatnich dekadach przekształcenia społeczno-gospodarcze, w tym procesy transformacji, liberalizacji, i globalizacji, a także szybki postęp technologiczny przyczyniają się do zmiany roli gospodarstw rolnych oraz zwiększenia ich powiązań z otoczeniem zewnętrznym. Rolnictwo, obok funkcji produkcyjnych, pełni aktualnie również funkcje społeczne i przyrodnicze. Otoczenie, w którym działają podmioty rolne staje się coraz bardziej złożone i trudne. Konkurencja zmieniła charakter z lokalnego i krajowego na międzynarodowy. Od 2016 r. przyjęto w Polsce nowe regulacje w kwestii gospodarowania gruntami rolnymi $w$ Polsce. W opracowaniu na podstawie przeprowadzonych badań zidentyfikowano najważniejsze bariery, które hamują funkcjonowanie i modernizacje gospodarstw rolnych użytkujących grunty pochodzące $\mathrm{z}$ ZWRSP. Według badanych rolników największy negatywny wpływ na rozwój gospodarstwa mają czynniki o charakterze cenowo-kosztowym (bez względu na formę zagospodarowania gruntów pochodzących z ZWRSP). Do najważniejszych barier respondenci zaliczyli niestabilne ceny skupu, wysokie koszty produkcji rolniczej, wysokie ceny na środki produkcji oraz brak kapitału na rozwój. W tej kwestii zaobserwowano zbieżność z wynikami badań innych autorów. Ankietowani rolnicy zwrócili uwagę także na skomplikowane procedury uzyskania dotacji z Unii Europejskiej oraz czynniki związane z 
dzierżawą (m.in. czynsz dzierżawny, regulacje formalno-prawnych dotyczące dzierżawy gruntów oraz jakość dzierżawionych gruntów). W kontekście wskazywanych przez rolników barier, wydaje się, że rozwój gospodarstw rolnych oraz wzrost ich konkurencyjności na rynkach międzynarodowych może być stymulowany przez odpowiednio ukierunkowaną politykę gospodarczą zapewniającą stabilną koniunkturę w rolnictwie, a w odniesieniu do gruntów pochodzących z ZWRSP - stabilne i długoterminowe umowy dzierżawy gwarantujące większe szanse zwrotu ponoszonych nakładów. Ponadto konieczna wydaje się także intensyfikacja działań informacyjnodoradczych o funduszach unijnych oferowanych w ramach Wspólnej Polityki Rolnej wspierających nakłady o charakterze inwestycyjnym oraz formach wspierania rozwoju gospodarstw rolnych w Programie Rozwoju Obszarów Wiejskich na lata 2014-2020.

\section{Literatura}

Bański, J. (2010). Znaczenie rolnictwa w gospodarce Polski (The role of agriculture in Polish economy). W: J. Bański (red.), Atlas rolnictwa Polski. Instytut Geografii i Przestrzennego Zagospodarowania im. Stanisława Leszczyckiego, Polska Akademia Nauk, Warszawa.

Chomicz, W., Balewski, B. (2012). Zadania i funkcje rolnictwa w warunkach polskiej gospodarki rynkowej XXI wieku (Tasks and functions of agriculture in the conditions of the Polish market economy of the 21st century). W: O. Samojlenko (red.), X Міжнародноі науково- практичноі конференціi, „Актуальні проблеми розвитку суспільства: історична спадщина, реаліі та виклики XXI століття" (X International scientific and practical conference "Current problems and development of agriculture: historical heritage, realities and challenges of the 21st century), Międzyregionalna Akademia Zarządzania Personelem w Łucku, Łuck.

Gołębiewski, J. (2014). Przemiany strukturalne w łańcuchu żywnościowym w Polsce (Structural changes in the food chain in Poland). W: Rolnictwo, gospodarka żywnościowa, obszary wiejskie - 10 lat w Unii Europejskiej. Praca zbiorowa pod redakcją N. Drejerskiej, Wydawnictwo SGGW. Warszawa, 17-30.

Kociszewski, K. (2014). Bariery i czynniki sprzyjające funkcjonowaniu gospodarstw ekologicznych w świetle wyników ogólnopolskich badań ankietowych (Barriers and factors favourable for functioning of organic farms in yhe light of nationwide questionnaire survey). RN SERiA, 16(2), 129-134.

Kołoszko-Chomentowska, Z., Sieczko, L. (2014). Gospodarstwo rolne jako podmiot w gospodarce narodowej (Agricultural farm as an entity in the national economy). Ekonomia i Zarzqdzanie, 6(1), 97-111.

Kondratowicz-Pozorska, J. (2015). Rola rolnictwa w kreowaniu trwałego rozwoju (The role of agriculture in the creation of sustainable development). Studia i Prace Wydziału Nauk Ekonomicznych $i$ Zarzqdzania Uniwersytetu Szczecińskiego, 40(2), 109-118.

Kosior, K. (2017). Wpływ uwarunkowań makroekonomicznych, politycznych i społecznych na konkurencyjność sektora żywnościowego w Polsce w kontekście procesów globalnych (Impact of macroeconomic, political and social conditions on the competitiveness of the food sector in Poland in the context of global processes). W: I. Szczepaniak (red.), Konkurencyjność polskich producentów żywności i jej determinanty (3). IERiGŻ_PIB, Warszawa, 9-44.

Krzyżanowski, J. (2014). Przyszłość rolnictwa, gospodarki żywnościowej i obszarów wiejskich (The future of agriculture, food economy and rural areas). W: Rolnictwo, gospodarka żywnościowa, obszary wiejskie - 10 lat w Unii Europejskiej. Praca zbiorowa pod redakcją N. Drejerskiej, Wydawnictwo SGGW. Warszawa, 916.

Kurdyś-Kujawska, A. (2013). Empiryczna weryfikacja czynników warunkujących rozwój gospodarstw rolnych (Empirical verification of the determinants of agricultural development). Journal of Agribusiness and Rural Development, 2(28), 143-150.

Nowak, A. (2013). Produktywność rolnictwa polskiego w kontekście jego konkurencyjności (The productivity of Polish agriculture in the context of its competitiveness). Folia Pomeranae Universitatis Technologiae Stetinensis. Oeconomica, 299(70), 159-168.

Nowak, A. (2015). Szanse i bariery rozwoju gospodarstw rolnych na przykładzie województwa lubelskiego (Opportunities and barriers to the development of farms on the example of the Lublin Province). Folia Pomeranae Universitatis Technologiae Stetinensis. Oeconomica, 317(78)1, 73-80. 
Nowak, A. (2016). Konkurencyjność wynikowa gospodarstw rolnych w Polsce na tle pozostałych krajów Unii Europejskiej w świetle danych FADN) The competitive performance of the farms in Poland comparing to other European Union countries basing upon FADN data). Zagadnienia Doradztwa Rolniczego, 3, 19-28.

Rocznik Statystyczny Pracy 2017 (Yearbook of Labour Statistics 2017). Pobrane 18 kwietnia 2018 z: https://stat.gov.pl/obszary-tematyczne/roczniki-statystyczne/roczniki-statystyczne/rocznik-statystycznypracy-2017,7,5.html.

Rocznik Statystyczny Rolnictwa 2017 (Statistical Yearbook of Agriculture 2017). Pobrane 18 kwietnia 2018 z: https://stat.gov.pl/obszary-tematyczne/roczniki-statystyczne/roczniki-statystyczne/rocznik-statystycznyrolnictwa-2017,6,11.htm.

Ryś-Jurek, R. (2016). Pozycja polskiego rolnictwa w Unii Europejskiej (The position of the Polish agriculture in the European Union). Zagadnienia Doradztwa Rolniczego, 3, 5-18.

Sondaż diagnostyczny (2017). Forma zagospodarowania nieruchomości z Zasobu Własności Rolnej Skarbu Państwa a konkurencyjność gospodarstw rolniczych w województwie warmińsko-mazurskim (The form of property development from the Agricultural Property Assets of the State Treasury and the competitiveness of farms in the Warmia-Mazury Voivodeship). Wydział Nauk Ekonomicznych, UW-M w Olsztynie.

Sulewski, P. (2008). Bariery i możliwości rozwoju gospodarstw rolnych w opiniach ich właścicieli (Barriers and chances for farm development in farmers opinions). ZN SGGW Ekonomika i Organizacja Gospodarki Żywnościowej, 67, 67-78.

Tomczak, F. (2005). Gospodarka rodzinna w rolnictwie. Uwarunkowania i mechanizmy rozwoju (Family agricultural economy: mechanism and development determinants). IRWIR PAN. Warszawa.

Wołoszyn, J. (2004). Wiedza istotnym zasobem w rolnictwie (Knowledge - essential resource in agriculture). Problemy Rolnictwa Światowego, 12, 124-133.

Do cytowania / For citation:

Łukiewska K., Juchniewicz M. (2018). Bariery rozwoju gospodarstw rolnych użytkujących grunty z Zasobu Własności Rolnej Skarbu Państwa. Problemy Rolnictwa Światowego, 18(2), 207-217; DOI: $10.22630 /$ PRS.2018.18.2.48

Łukiewska K., Juchniewicz M. (2018). Barriers to the Development of Farms Using Land from the Agricultural Property Resources of the State Treasury (in Polish). Problems of World Agriculture, 18(2), 207-217; DOI: 10.22630/PRS.2018.18.2.48 